Çukurova Üniversitesi Mühendislik Mimarlık Fakültesi Dergisi, 32(4), ss. 39-54, Aralık 2017

\title{
Demiryolu Mimarisinin Korunma Sorunları ve Kırklareli Tren İstasyonu Yapılarının Yeniden Kullanımı için Bir Öneri
}

\author{
Ali YILDIZ ${ }^{* 1}$ \\ ${ }^{1}$ Bozok Üniversitesi, Mühendislik-Mimarlık Fakültesi, Mimarlık Bölümü, Yozgat
}

Geliş tarihi: 03.08.2017

Kabul tarihi: 19.12 .2017

$\ddot{\mathbf{O} z}$

Türkiye'deki demiryolu hatları üzerinde çok sayıda istasyon binası inşa edilmiştir. Ancak bu yapıların bir kısmı demiryolu teknolojisindeki gelişmeler, kullanıcı ihtiyaçlarının farklılaşması, demiryolu hat güzergâhlarının değişmesi gibi çeşitli nedenlerle özgünlüğünü yitirmiş veya yıkılarak yok olmuş, önemli bir kısmı da yok olmaya yüz tutmuştur. Yıllardır kullanım dışı olan Kırklareli Tren İstasyonu günümüzde sadece ilde düzenlenen etkinliklere ev sahipliği yapmaktadır. Alanda bulunan istasyon yapılarından özellikle yolcu (gar) binası, fen memuru binası ve lokomotif deposunun sürekli kullanımının olmaması ve buna bağlı olarak da bakımsız kalmaları nedeniyle yapılar günden güne tahrip olmaktadır. İstasyon alanı ve içinde bulunan yapılar şehrin kimliğine ve alanın tarihi dokusuna uygun olarak rehabilite edilmeli ve kent yaşamına aktif olarak katılmalıdır. Bu çalışmada demiryolu mimari mirasının korunma sorunları araştırılarak, çözüm önerileri getirilmiştir. Kullanım dışı kalarak kaderlerine terk edilen Kırklareli Tren İstasyonu yapılarının mimari, tarihi ve endüstriyel bir miras olarak korunması gerekliliği temel ilke kabul edilerek; Kırklareli istasyon alanı içerisinde bulunan yapıların, özgün mimari niteliklerinin korunarak yüklenecek yeni fonksiyonlar ile gelecek nesillere aktarılması için öneriler geliştirilmiştir.

Anahtar Kelimeler: Demiryolu mirası, Kırklareli tren istasyonu, Koruma, Yeniden kullanım

\section{Problems of Preservation in Railway Architecture and a Proposal for the Re-use of Kirklareli Train Station Buildings}

\begin{abstract}
A large number of station buildings were built on the railway lines in Turkey. However, some of these buildings have lost their authenticity due to various reasons such as developments in railway technology, differentiation of user needs, change of railway line routes, or they have been damaged and collapsed. Kirklareli Railway Station, which has been out of use for years, is now host to events organized only on the city. Due to the no constant use of station building, engineer building and locomotive depot from the station buildings in the area, and due to the neglect of their maintenance, the buildings are damaged from day to day. The station area and the buildings in it must be rehabilitated in accordance with the identity of
\end{abstract}

"Sorumlu yazar (Corresponding author): Ali YILDIZ, ali.yildiz@bozok.edu.tr 

Öneri

the city and the historical texture of the area and should actively participate in the city life. In this study, problems of preserving of railway architectural heritage were investigated and solution proposals were improved. The necessity of preserving Kirklareli Train Station buildings, which are abandoned and out of use today, as an architectural, historical and industrial heritage was accepted as the main principle. Accordingly, proposals have been developed to transfer the buildings within Kurklareli Train Station area to next generations by preserving their original architectural qualifications and giving new functions.

Keywords: Railway heritage, Kırklareli train station, Conservation, Re-use

\section{GíRiș}

Türkiye'de, temelleri Osmanlı döneminde atılan demiryolu hatlarının yapımını büyük oranda yabancı şirketler gerçekleştirmiş, hatların işletmesi de yine bu şirketlerce sağlanmıştır. Cumhuriyetin ilanından sonra geliştirilen ulusal politika çerçevesinde mevcut demiryolları millileştirilerek, yeni inşa edilen hatlar ile ülke içindeki demiryolu ağ1 genişletilmiştir. 1950'li yıllara kadar ulaşım sistemleri içerisinde önemli bir paya sahip olan demiryolları, karayollarındaki yatırımların daha fazla olmasi ve demiryolu teknolojisindeki gelişmelerin ülkemizdeki hatlara yansıtılmaması gibi nedenlerle ulaşım sektörü içerisindeki gücünü giderek kaybetmeye başlamış ve insanlar tarafından daha az tercih edilir hâle gelmiştir. Buna bağlı olarak trafik yoğunluğu azalan hatların bir kısmı ulaşıma kapatılmıştır. Ayrıca, hatlarda kullanılan buharlı lokomotiflerin yerini dizel ve elektrikli lokomotiflerin almasiyla buharlı lokomotiflere su, kömür gibi malzemelerin verildiği ara istasyonlar kullanım dışı kalmıştır. Bunun yanında demiryolu taşıtlarının gelişmesiyle birlikte vagon ve lokomotiflerin bakım-tamirinin yapıldığı birçok yapı da ya yetersiz kalmış ya da yapılan yeni eklerle kullanımına devam edilmiştir. $\mathrm{Bu}$ ve benzeri nedenlerle kullanım dışı kalan istasyon alanları üzerindeki yapılar terk edilmiş, dolayısıyla işlevlerini yitirmiştir. Metruk hâldeki bu istasyon yapıları gerek bakımsızlık gerekse çevresel etkiler nedeniyle yok olma tehlikesiyle karşı karşıya bulunmaktadır.

İktisadi ve askeri öneminden dolayı Balkan Harbi'nden hemen önce, 1910-1912 y1lları arasinda Rumeli Demiryolu Hattı'ndan Kirklareli'ne uzatılan $46 \quad$ kilometrelik Büyükmandıra-Kırklareli Hattı Şark Demiryolları
Kumpanyası tarafindan inşa edilerek işletmeye açılmıştır [1-3]. Rumeli Demiryolu ana hattı, Kırklareli sınırları içerisinde Seyitler, Lüleburgaz, Alpullu, Büyükmandıra, Pehlivanköy üzerinden geçerek 56 kilometrelik bir mesafe kat ettikten sonra Edirne sınırlarına ulaşır. Ana hattan Büyükmandıra Tren İstasyonu'nda ayrılan demiryolu hatt1, Nadırlı - Babaeski - Karamesutlu - Taşağıl - Nacak - Kavaklı istasyonlarını geçerek Kırklareli il merkezinde son bulur.

Kırklareli demiryolu hattında 1987 y1lına kadar yolcu taşımacılığ 1 yapılırken, bu yıldan sonra yolcu taşımacılığı son bulmuştur [4]. Kırklareli sınırları içerisinde aktif olarak; Alpullu Gar Şefliği, Pehlivanköy İstasyon Şefliği, Lüleburgaz İstasyon Şefliği hizmet vermektedir. Kırklareli Büyükmandıra Hattı üzerinde, faal olarak çalışan istasyon bulunmamakla birlikte istasyon alanları da terk edilmiş hâldedir. Kırklareli istasyon alanının rehabilite edilerek bütüncül bir yaklaşımla alanda bulunan istasyon yapilarının restore edilmesi, hat üzerinde bulunan diğer istasyon alanları için de koruma bilinci oluşmasına katk1 sağlayacaktır. Nitekim Babaeski istasyon alanında bulunan yapılar metruk hâlde olup; Kavaklı istasyon binası yıkılmaya yüz tutmuş, Taşağıl istasyon binası ise yıkılarak yok olmuştur. Demiryolu hattı üzerindeki bu yapılara yeni işlevler kazandırılması sürdürülebilir bir koruma yaklaşımı sağlayacaktır.

Kırklareli istasyon yapılarının bulunduğu bölge şehrin merkezinde, taşıt trafiğinden ve gürültüden uzak, yeşil bir alan niteliği taşımaktadır. Bu nedenle insanlar tarafindan spor yapma, dinlenme ve mesire yeri olarak kullanılmakta, düzenlenen birçok etkinliğe de ev sahipliği yapmaktadır. Ancak başta yolcu binası ve lokomotif deposu olmak üzere metruk hâldeki istasyon yapıları, 
günden güne yok olurken alan içerisinde de kötü bir görünüm oluşturmaktadır. Dolayısıyla istasyon yapıları tarihi kimliklerine uygun olarak restore edilmeli ve yapılara verilecek yeni işlevler ile; alanın tarihi, sosyal ve kültürel bir merkez hâline getirilmesi yönünde çalışmalar yürütülmelidir. $\mathrm{Bu}$ çerçevede yapılar bir kompleks olarak ele alınıp birbirini tamamlayan işlevler yapılara yüklenebileceği gibi, tek yapı ölçeğinde verilecek işlevler ile daha özgün fikirler geliştirilebilir.

Çalışmada demiryolu mimarisinin korunma sorunları araştırılarak, çözüm önerileri getirilmiştir. Ayrıca Kırklareli istasyon alanında bulunan yapıların özgün mimarilerinin ve yapım sistemlerinin korunarak yeni işlevleri ile yaşatılması için öneriler geliştirilmiştir. Yapıların mevcut durumları rölöve çalışmaları ve resimler ile belgelenerek, yapılar üzerindeki izler ve arşiv araştırmaları ışı̆̆ında restitüsyon projeleri hazırlanmıştır. Elde edilen bulgular değerlendirilerek restorasyon önerileri sunulmuştur.

\section{DEMIRYOLU GELIŞiMI VE KORUNMA SORUNLARI}

Demiryollarının aktif olarak ulaştırma alanında kullanılması ile birlikte, bu yeni ulaşım sisteminin işleyişinin düzenli bir şekilde gerçekleştirilebilmesi için birtakım tesis ve yapıların inşası da zorunlu hâle gelmiştir. İstasyonun konumuna göre; yolcuların bekleme ve diğer ihtiyaçlarına cevap verecek binaların yanında, demiryolu çalışanlarının barınma ihtiyaçlarının karşılandığı, taşıtların bakımonarımlarının, yük indirme-yüklemesinin yapıldığı binalara da gereksinim duyulmuştur. Bu ve benzeri ihtiyaçları karşılamak için istasyon alanlarında; yolcu binaları, yük ambarları, lojmanlar, yatakhaneler, tamir ve bakım atölyeleri, su depolar1, postahaneler, polis veya jandarma karakolları ile bekçi ve kapıcı barakaları gibi yardımcı hizmet binaları inşa edilmiştir [4].

Demiryolu yapıları yüklendikleri fonksiyonlara bağlı olarak plan organizasyonu, cephe ve kütle çözümleri ile yapım tekniği ve malzeme kullanımları yönüyle mimari açıdan yeni bir tür yapılar grubu olarak ortaya çıkmıştır. Özellikle geniş açıklıkların ara mesnet kullanılmadan geçilmesi için geliştirilen çözümlerin yanında metal ve cam malzemelerin ilk kullanıldı ğ1 yapılardan olması dolayısıyla demiryolu mimarisi yap1 teknolojisinin ve mimarinin gelişimine katk1 sağlamıştır. Çeliğin bol olması birçok yapıda kullanımına da olanak sağlamıştır. Özel üretilen çelik profiller döşeme oluşturmak için sıklıkla kullanılmış, bazı hâllerde ise demiryolu rayı olarak üretilen I profiller yap1 elemanı bünyesine girmiştir. Bu profiller yoğun sirkülasyonun veya açıklığın fazla olduğu döşemelerin inşasında volta döşeme oluşturmak amacıyla kullanılmıştır.

Demiryolu mimarisinin Avrupa ve Amerika'daki örnekleri, mimari öğeleri ve büyüklükleri ile Türkiye'deki örneklerinden belirgin bir biçimde farklılık göstermektedir. Ancak, Osmanlı İmparatorluğu'nun yapımına önem verdiği belirli merkezlerdeki gar binaları ile hattı inşa eden yabancı şirketlerin ulusal mimarisini en iyi şekilde yansıtma imkânını bulduğu noktalardaki gar binaları gerek mimari üsluplarıyla gerekse biçim ve boyutlarıyla farklı özellikler sergilemektedir $[5,6]$. Bunun dişında kalan istasyonlarda, aynı hat üzerindeki yolcu binalarının çoğunda küçük değişikliklerle birlikte benzer projeler uygulanmıştır. İstasyon alanlarındaki hizmet binalarının mimarisi yolcu (gar) binalarına nazaran sade ve gösterişsiz olsa da fonksiyonun öne çıktığı bu yapılar cephe karakterleri itibariyle birbirleri ve yolcu binaları ile bütünlük içerisindedir [4].

Cumhuriyet öncesinde Türkiye'de inşa edilen hatların büyük bir kısmı farklı yabancı şirketler tarafından yapılmıştır. Şirketlerin temel amacı ulaşımı sağlamaktan çok ülkenin doğal kaynaklarının sömürülmesi ve hükümetin sağladığ1 kilometre garantisi ile karlarının arttırılması olmuştur [3,5]. Bu tutum gösterişsiz, sade, ucuz istasyon projeleri ile demiryolu mimarisi üzerinde yansımasını bulmuştur. Bunlara rağmen, İngiliz şirketler tarafindan inşa edilen istasyon binaları; tren sundurmalarının kullanılması ve yeni gelişen istasyon tipleri ile Avrupa'daki örneklerin gelişimini yansıtırken, Alsancak ve Basmane 
garlarında olduğu gibi daha küçük boyutta kalmıştır [5]. Demiryolu mimarisi genel olarak, eksik bir şekilde sadece gar binaları ile özdeşleştirilmektedir. Ancak diğer hizmet binaları ile birlikte değerlendirilmesi gereken geniş bir kavramdır. Gar binaları mimari özellikleri ve işlevleri ile ön plana çıksa da demiryolu binaları bir bütün olarak demiryolu mirasının önemli bir parçasını oluşturmaktadır. Demiryolu hatları üzerinde çok sayıda bina inşa edilmiştir. $\mathrm{Bu}$ yapıların önemli bir kısmı çeşitli nedenlerle kullanım dışı kalarak harap olmuş, bazıları ise tamamıyla yıkılmıştır. Demiryolu yapıları mimari, tarihi ve endüstriyel bir miras olarak değerlendirilmelidir.

Demiryolu mirasının tanımlanması ve korunması oldukça yeni bir konudur. İlk olarak endüstri yapılarının korunması ile gündeme gelmiş, seksenlerin ikinci yarısı ve doksanlarla beraber geniş şekilde çalışılmaya başlanmıştır. Her ne kadar demiryolu makinelerinin, özellikle vagonlar ve lokomotifler gibi tekil elemanların korunmas1 yönündeki çalışmalar XX. yüzyıl ortası itibarı ile başlamış olsa da bütüncül çalışmalar son $30 \mathrm{yıl}$ içinde yoğunlaşmıştır. Bu çalışmalarda Avrupa'da başı çeken İngiltere olmuş, Amerika kıtasında ise Kanada bu çalışmalara öncülük etmiştir [7]. ICOMOS tarafindan 1999 yılında, uluslararası düzeyde önemli olan demiryollarının Dünya Mirası Listesi'ne aday olarak belirlenebilmesi için esas olacak kriterler yayınlanmıştır. Buna göre bir demiryolu hattı ve çevresinin Dünya Mirası Listesi'ne aday olarak belirlenebilmesi için; deha ürünü yaratıcı bir iş olması, yenilikçi teknolojiden etkilenmiş ve teknolojiyi etkilemiş olması, çarpıcı veya tipik bir örnek olması, ekonomik veya sosyal gelişmelerin göstergesi olması yönleriyle değerlendirilmesi önerilmiştir [8]. İsviçre ve İtalya'nın Albula/Bernina Bölgeleri'ndeki Rhaetian Demiryolu, Hindistan Dağ Demiryolları ve Avusturya'daki Semmering Demiryolu üzerinde inşa edilen önemli mühendislik yapılarının yenilikçi teknolojileri yansıtması ve geçtiği bölgelerdeki sosyal, ekonomik gelişmeleri etkilemesi, bu hatların Dünya Mirası Listesi'ne alınmasını sağlamıştır [9]. Dünya üzerindeki demiryolu mirasının koruma yaklaşımı açısından incelenmesi Türkiye'deki demiryolu mirasının korunması için yol gösterici olacaktır. Özellikle hat üzerinde inşa edilen köprü (Varda Köprüsü) ve tünellerin önemli mühendislik yapıları olması yönüyle dünyadaki örnekleriyle benzerlik gösteren Pozant1-Adana Demiryolu Hatt1, benzer koruma yaklaşımlarının uygulanabileceği bir hattır.

Demiryolu mirasının kapsadığı alan; demiryolu arşivleri (yazılı metinler, çizimler, projeler, anlaşmalar); hareketli tüm makineler (vagonlar, lokomotifler); yapılar (istasyon-gar binaları, bakım atölyeleri, tren sundurmaları ve hangarlar, malzeme ve yük depoları, su depoları, köprüler ve viyadükler); bu yapılarla ve hattın tamamı ile bir bütün oluşturan kentsel ve kırsal alanlar, sanayi tesisleri, doğal panoramalar ve manzaralar; altyap1 ve sinyalizasyon sistemleri ile ilgili tüm ekipmanlar; demiryolu ile ilgili tüm taşınabilir nesneler (saatler, mobilyalar, kantarlar vs.) olmak üzere altı başlık altında toplanır. Demiryolu mirası küçük bir el aletinden devasa büyüklükteki binalara kadar çok zengin bir hazine niteliğindedir $[7,10]$. Burada demiryolları mirasının kentlerdeki metro sistemlerini de içerdiğini unutmamak gerekir. Hâlen kullanılmakta olan Londra ve Moskova metroları ile ilgili koruma çalışmaları yapılmaktadır. $\mathrm{Bu}$ çalışmalar özellikle istasyonların özgün hâllerinin korunması üzerine yoğunlaşmıştır. Türkiye bu bakımdan ayrıcalıklı bir örneğe sahiptir. 19. yüzyıl sonlarında ortaya çıkan bu ulaşım aracının New York ve Londra'dan sonra üçüncü örneği İstanbul'da, Karaköy ve Tünel semtleri arasında işlemeye başlamıştır. Teknolojisi neredeyse değişmeden işleyen bu hat korunması gereken önemli bir demiryolu mirasıdır [7]. Benzer şekilde Taksim-Tünel semtleri arasındaki nostaljik tramvay hattı da demiryolu mirasının önemli bir parçasını oluşturmaktadır.

Demiryolu mirası günümüze kadar, İngiltere de dâhil olmak üzere tüm dünyada hak ettiği ilgiyi tam anlamıyla bulamamıştır. Modernleşme sürecinde 1960'larda kapatılan birçok demiryolu hattı dolayısıyla yitirilen önemli demiryolu yapıları bir bilinç oluşmasına neden olmuştur. 1977 yılında 'SAVE Britain's Heritage' kapsamında düzenlenen 'Off the Rails' adlı sergi İngiltere'de demiryoluna olan ilgiyi arttırmış, bu tarihten sonra mimari ya da tarihsel öneme sahip yapıların ve demiryollarının 
korunmaları gündeme gelmiştir. Örneğin, 1980'lerde Manchester Merkez İstasyonu'nun sergi salonuna dönüştürülmesiyle demiryolu yapıları yıkılmak yerine koruma altına alınmaya başlanmıştır. İngiltere'de ana işlevi kömür taşımacılığı olan ve kısa mesafelerde hizmet veren bazı demiryolu hatları, sözü edilen işlevi yitirmesiyle birlikte kullanım dışı kalmış, ancak kısa bir süre sonra farklı işlevler için yeniden kullanıma sokulmuştur. İngiltere'nin genelinde 1997 yılı itibariyle bu şekilde işlev değiştirerek koruma altına alınmış altmışa yakın demiryolu hattı bulunmaktadır $[10,11]$. Çeşitli ülkelerde ve kültürlerde teknik anitlar olarak değerlendirilen demiryolu yapıları aslında tarihi binaların ana parçası olarak görülmelidir. 19. yüzyılda İngiltere'den diğer ülkelere hızla yayılan demiryolu ulaşımı, özel bina tiplerinin ve özel lokomotif sınıflarının da diğer ülkelere yayılmasını sağlamıştır. Böylece bazı ülkelerde yok olan istasyon yapılarının veya taşıtlarının başka bir ülkede özgün hâlleriyle bulunabilmesi demiryolu mirası için evrensel açıdan son derece çekici bir yön oluşturmuştur (Şekil 1) [10].

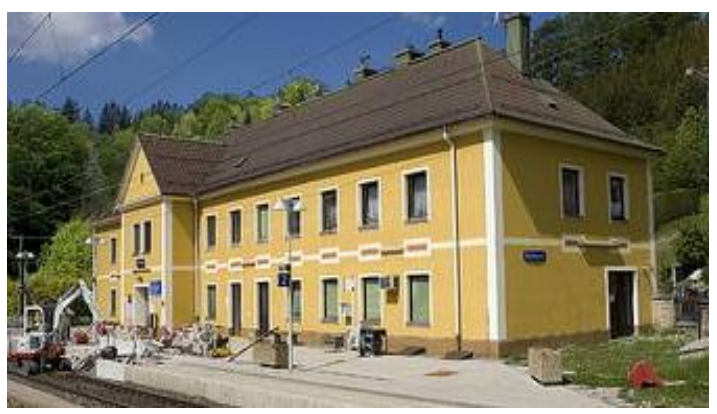

Şekil 1. Semmering demiryolu hattı üzerindeki bir istasyon binas1, Avusturya [9]

Demiryolu mirasının korunmasının önündeki en büyük engel, sahip olunan değerlerin bilinmemesi, eksik değerlendirilmesidir. Kişiler, hakkında bilgi sahibi oldukları alanları ve yapıları daha çok benimsemekte ve korunmaları için çaba sarf etmektedirler. Demiryolu yapıları bir bütünün işlevsel parçalarıdır. Bu bütün parçalandığında her yapının varlığı daha az önemli hâle gelir. Bunun sonucunda yapılar yalnızca mimari değerleri ya da sağladıkları mekânsal olanaklar ile değerlendirilir hâle gelmektedir [11].
Demiryolu mimari mirasının korunması için öncelikle geniş kapsamlı arşiv ve belgeleme çalışmalarının yapılması gereklidir. Mevcut yapı stoku ile arşiv kayıtları karşılaştırılarak, güncel envanter bilgisi oluşturulmalıdır. Yapılacak rölöve çalışmaları ile yapıların geçirdiği onarımlar ve değişimler tespit edilerek, özgün karakterlerinin belirlenmesine yönelik restitüsyon projeleri hazırlanmalıdır. Kullanım dışı kalarak yok olma tehlikesi ile karşı karşıya olan yapılar için restorasyon çalışmaları hızla başlatılmalıdır. İstasyon alanlarına birbiriyle ilişkili yapılar grubunun bir arada olması, dönemin inşaat ve demiryolu teknolojisini günümüzde de önemli ölçüde yansıtması nedenleriyle bütüncül bir koruma anlayışı ile yaklaşılmalıdır. Yapılacak restorasyon çalışmalarında istasyon alanlarında bulunan tüm yapılar ile birlikte demiryolu makine ve teçhizatları da koruma altına alınmalıdır. Ayrıca yapıların inşa edildiği dönemin teknolojisini yansitan buharlı lokomotifler ve nostaljik vagonlar ile istasyon alanları ilişkilendirilerek alanının tarihi kimliğiyle uyumlu bir atmosfer oluşturulması yönündeki yaklaşımlar ile istasyon alanlarının çekiciliği arttırılmalıdır. Böylece yapıların yakınına yerleştirilecek demiryolu taşıtları ile istasyon alanlarında bütünlük sağlanabilecek ve insanların ilgisi arttırılarak demiryolu mirasının korunmasına yönelik bilinç oluşturulabilecektir.

\section{KIRKLARELI TREN ISTASYONU YAPILARI İÇIN KORUMA ÖNERISI}

Kırklareli Tren İstasyonu yapılarının bulunduğu alan, il merkezinde, adını da verdiği İstasyon Mahallesi'nde, merkezi bir konumdadır. İstasyon alanındaki yapılar demiryolu hattı boyunca bir dizi oluşturacak şekilde yan yana konumlandırılmıştır. Demiryolu işletmesinin verimli olarak yapılabilmesi için alanda toplam on iki yapı inşa edilmiş, günümüzde ise bunlardan dördü tamamıyla yok olmuştur. Yapılar topluluğunu; yol bekçi binası, emtia (mal) ambarı, jandarma binası, umumi hela, yolcu (gar) binası, makasçı binası, çamaşırhane, fen memuru binası, amele ve fen memuru ambarı, yatakhane, su haznesi, lokomotif deposu oluşturmuştur (Şekil 2-4). 


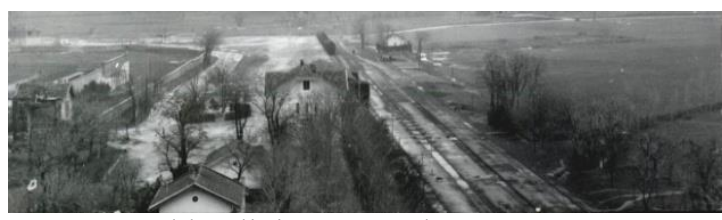

Şekil 2. Kırklareli istasyon alanını gösteren 1956 tarihli bir resim (Anonim)

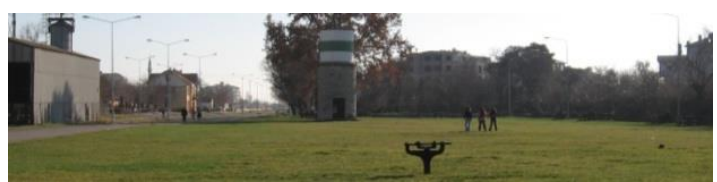

Şekil 3. Lokomotif deposundan istasyon binası istikametini gösteren resim
Yapıların yapım tarihi ve mimarı kesin olarak bilinemese de, hattın 1910 yılında yapımına başlandığ1 ve 1912 yılında işletmeye açıldığ dikkate alınırsa, yapıların da bu tarihler arasında inşa edildiği anlaşılmaktadır. Yolcu (gar) binasının orijinal projesi Şark Demiryolları Kumpanyası tarafindan yabanci mimarlara Fransizca olarak hazırlatılmıştır [4]. Alandaki yapılar cephe karakteri, yapım tekniği ve bezemeleri itibariyle birbirleri arasında bütünlük göstermektedir. Neoklasik tarzda inşa edilen yapılar, mimari elemanları ve bezemeleriyle üslup özelliklerini yansitmaktadır.

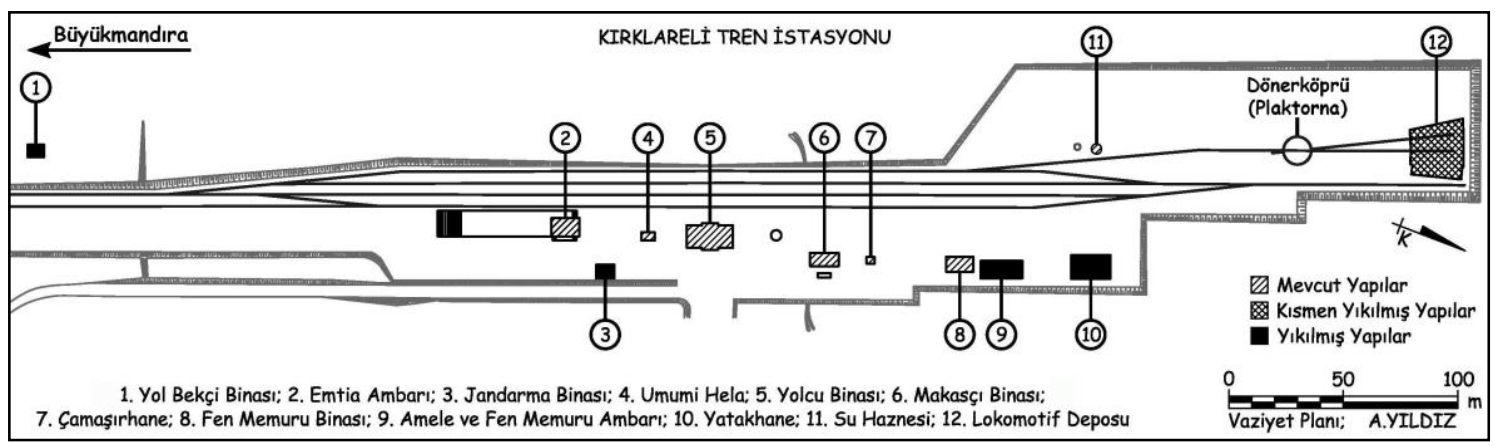

Şekil 4. Kırklareli tren istasyonu vaziyet planı [4]

Kırklareli istasyon alanında bulunan yapılar özgün işlevlerini yitirerek kullanım dışı kalmıştır. $\mathrm{Bu}$ yapıların mimari ve endüstriyel bir miras olarak yaşatılması için restore edilerek yeniden kullanıma açılmaları en ekonomik koruma yaklaşımı olacaktır. Alandaki yolcu (gar) binasının-butik otel veya ek hizmet binası, lokomotif deposununrestoran\&düğün salonu veya konferans salonu, fen memuru binasının-pastane, emtia ambarınınseminer salonu, makasçı binasının-kafeterya, su haznesinin-büfe ve çay ocağı, umumi helanıntuvalet, çamaşırhanenin-güvenlik binası olarak yeniden işlevlendirilmesi önerilmektedir. Ayrıca, alana yerleştirilecek buharlı lokomotif ve nostaljik vagonlar ile istasyonunun tarihi kimliğinin ve atmosferinin yansitılmasi hedeflenmektedir. Emtia ambarının yakınına yerleştirilecek iki adet vagonun içerisinin seminer ve kitap okuma salonu olarak düzenlenmesi, benzer şekilde su haznesinin yakınına yerleştirilecek vagonun içerisinin de çayevi olarak tanzim edilmesi yapıların işlevselliğine de katkı sağlayacaktır (Şekil 5, Çizelge 1).

İstasyon yapılarının bulunduğu alanın toplam yüzölçümü 42713,62 metrekare olup, tarihi yapıların bulunduğu 27976,65 metrekarelik kısım, Kültür ve Tabiat Varlıklarını Koruma Yüksek Kurulu'nun 12.06.2009/2572 say1l kararı kapsamında tescillenerek koruma altına alınmıştır. Alan içerisinde bulunan yapılarla birlikte yakın çevresinin de değerlendirilerek, bölgenin rekreasyon alanı olarak düzenlenmesi bütüncül bir koruma yaklaşımı için önem arz etmektedir. Bu kapsamda oluşturulacak yürüyüş ve bisiklet yolları ile dinlenme alanları, çocuk parkı, spor sahaları bölgenin şehir için önemli bir odak noktası hâline gelmesini sağlayacaktır. Ayrıca toprak ile doldurularak kapatılan dönerköprünün bulunduğu noktanın havuz olarak düzenlenmesi, alanın tarihi dokusuna uygun yaklaşım olacaktır (Şekil 5). 


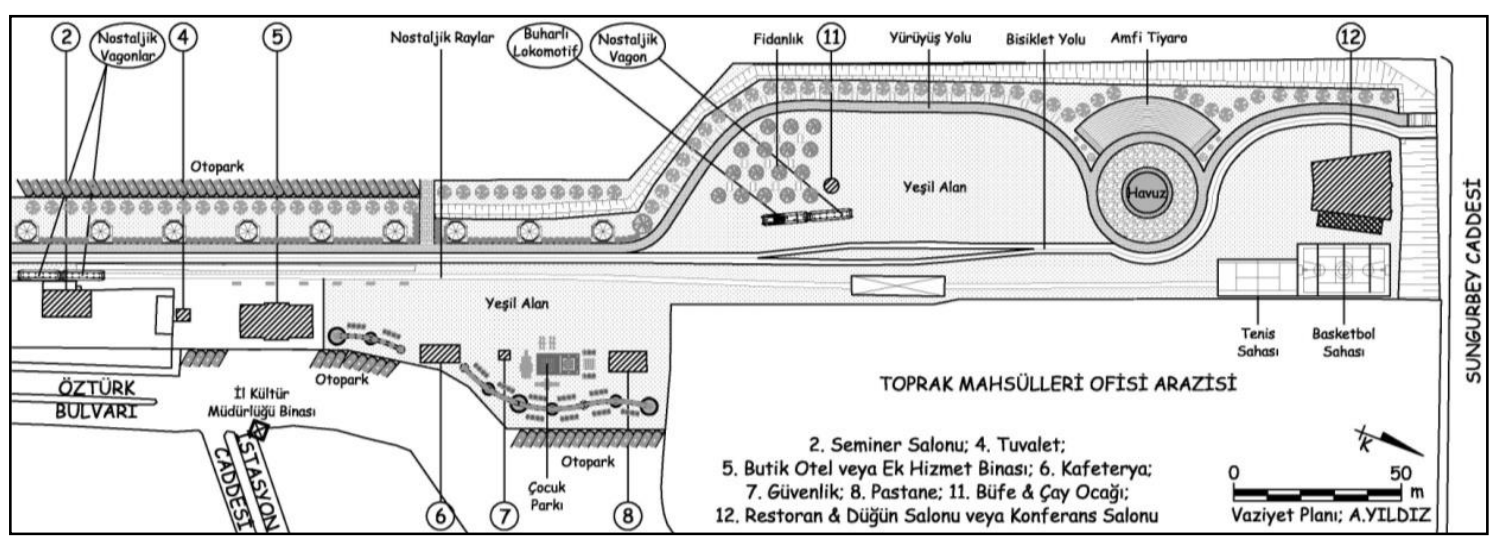

Şekil 5. Kırklareli istasyon alanının ve istasyon yapılarının yeniden değerlendirilmesi için öneriler

Çizelge 1. Kırklareli istasyon yapılarının mevcut kullanımları - yeni kullanım önerileri

\begin{tabular}{|c|l|l|l|r|}
\hline No & Yapının İsmi & Mevcut Kullanımı & Önerilen Kullanım & Alanı \\
\hline 2 & Emtia Ambarı & Kafeterya & Seminer Salonu & $96 \mathrm{~m}^{2}$ \\
\hline 4 & Umumi Hela & Tuvalet & Tuvalet & $14,5 \mathrm{~m}^{2}$ \\
\hline 5 & Yolcu (Gar) Binası & Kullanılmıyor & Butik Otel veya Ek Hizmet Binası & $435,5 \mathrm{~m}^{2}$ \\
\hline 6 & Makasçı Binası & Kafeterya & Kafeterya & $81 \mathrm{~m}^{2}$ \\
\hline 7 & Çamaşırhane & Depo & Güvenlik Binası & $10,5 \mathrm{~m}^{2}$ \\
\hline 8 & Fen Memuru Binası & Kullanılmıyor & Pastane & $134,5 \mathrm{~m}^{2}$ \\
\hline 11 & Su Haznesi & Kullanılmıyor & Büfe \& Çay Ocağ1 & $15 \mathrm{~m}^{2}$ \\
\hline 12 & Lokomotif Deposu & Kullanılmıyor & Restoran \& Düğün Salonu veya Konferans Salonu & $488 \mathrm{~m}^{2}$ \\
\hline
\end{tabular}

\subsection{Emtia Ambarı}

Dikdörtgen planlı, uzun kenarı demiryolu hattına paralel uzanan, tuğla malzemeden kâgir yığma olarak inşa edilen yapının çatısı; tek dikmeli ahşap asma çatı makasları üzerine oturtulmuş beşik çatıdır. Bodrum ve zemin kattan oluşan binanın bodrum kısmına giriş düzenlenmemiştir. Yapının peron ve giriş cepheleri ile yan cepheleri simetrik bir düzen ile inşa edilmiştir; yan cephelerinde birer pencere, peron ve giriş cephelerinde ise ikişer yatay sürme kapı ile kapıların ortasında açılan küçük birer pencere yer almaktadır. Ahşap doğramalı pencerelerin dış kısımlarında metal korkuluklar düzenlenmiştir. Pencere ve kap1 açıklıkları basık kemerle geçilmiş, kemerlerin tepe noktalarında kilit taşı görünümünde bezemeler yapılmıştır. $\mathrm{Bu}$ açıklıkların etrafı silmeler ile çevrilmiş, böylece kapı ve pencereler belirginleştirilerek cephe hareketlendirilmiştir.
Yapının iç kısmında, ambar memuru için ahşap malzemeden küçük bir bölme oluşturulmuştur. İldeki demiryolu ile yapılan taşımacılığın büyük ölçüde azalması neticesinde bina kullanım dışı kalmış, bir süre sonra da kiraya verilmiştir. Bu kapsamda yakın zamana kadar bina, eğlence merkezi olarak hizmet vermiştir. Günümüzde ise, yap1 kafeterya olarak kullanılmakta olup, bu şekildeki kullanımı için yapı içerisinde koruma anlayıșından uzak olarak bazı tadilatlar ve ekler yapılmıştır. Yapının iç kısmında mutfak tanzim edilmiş, çatı makaslarının alt kısımları kapatılarak ara tavan oluşturulmuş, iç duvar yüzeyleri duvar kâğıdı ile kaplanmış ve peron cephesine ek bir sundurma yapılarak etrafi kapatılmıştır. Ayrıca sağ yan cephesine bitişik olarak ikinci bir sundurma inşa edilmiş, yapılan bu niteliksiz ekler sonucunda yap1 özgünlüğünü yitirmiştir (Şekil 6-7). 


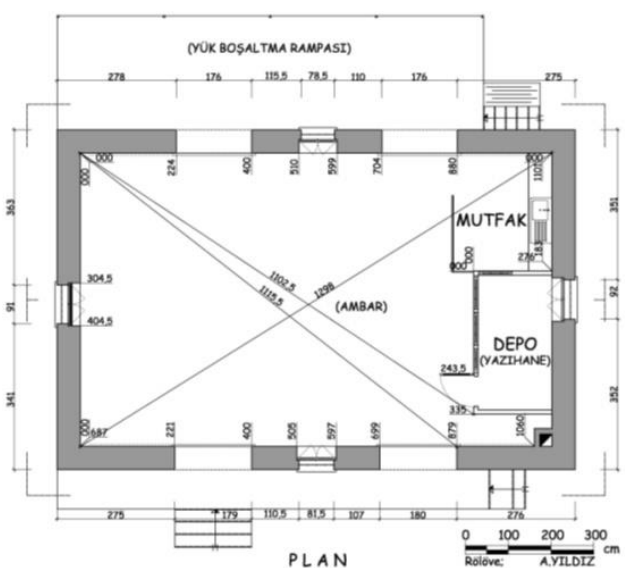

Şekil 6. Emtia ambarı, rölöve

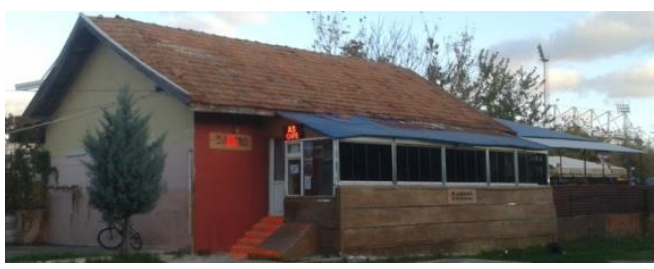

Şekil 7. Emtia ambarı, peron cephesi

Yapıya ek bir yük getirilmeden ve özgün plan şeması korunarak yüklenecek yeni fonksiyonlar; seminer salonu, sanat galerisi, sergi salonu, kütüphane, bar, kafeterya ve kiraathane olarak sıralanabilir. Restorasyon önerisi ile seminer salonu olarak yeniden işlevlendirilen yapının, şehirdeki çeşitli kurumlar tarafından düzenlenecek kurs ve seminerlere ev sahipliği yapması öngörülmektedir (Şekil 8).

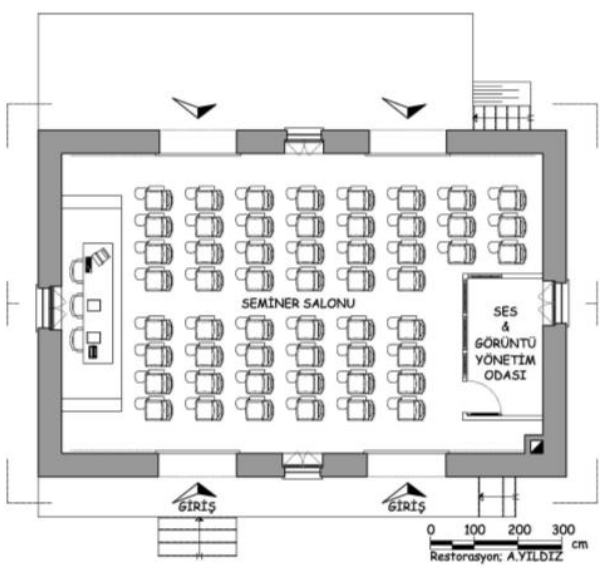

Şekil 8. Emtia ambarı, restorasyon
Ayrıca yapının peron kısmındaki rayların üzerine yerleştirilecek nostaljik vagonlardan birinin iç kısmının sergi salonu, diğerinin de ek bir seminer salonu veya kitap okuma salonu olarak teşrif edilmesi ile daha aktif ve verimli bir kullanım sağlanabilecektir.

\subsection{Umumi Hela}

Yolcuların kullanımı için gar binasının hemen yanında, tuğla yığma olarak inşa edilen yapının üzeri ahşap beşik çatı ile örtülmüştür. Yapının pencere ve kapılarının etrafı silmelerle çevrilmiş, kapıların üst kısımlarında kilit taşı görünümlü süslemeler yapılmıştır. Ayrıca her iki yan cephede de çatı arası hizasındaki rozet şekilli bezemeler ile cepheye hareket kazandırılarak, estetik bir görünüm sağlanmıştır. Yapı günümüzde de tuvalet olarak kullanılmakta olup, özgün işleviyle seminer salonu için tuvalet olarak hizmet vermesi hedeflenmektedir (Şekil 9-10).

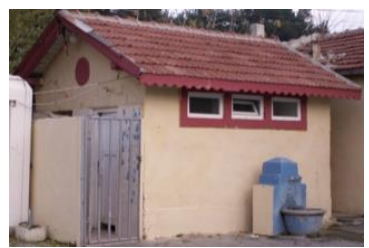

Şekil 9. Umumi hela, peron cephesi

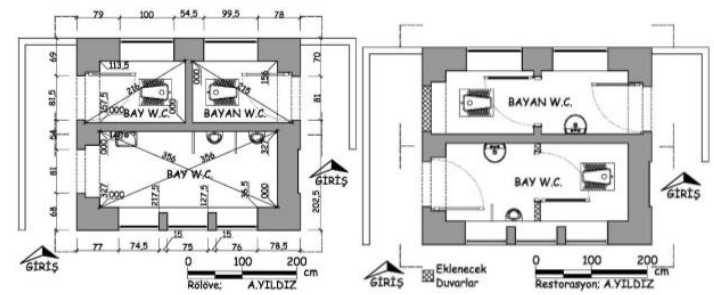

Şekil 10. Umumi hela, rölöve ve restorasyon

\subsection{Yolcu (Gar) Binası}

Dikdörtgen planlı, uzun kenarı demiryolu hattına paralel olarak inşa edilen bina, bodrum, zemin ve birinci kat olmak üzere üç kattan oluşmaktadır. Bina simetrik bir planlama anlayışıyla inşa edilmiştir. Giriş holü dışarıya doğru taşırılarak ana kütleden ayrılmış böylece cepheye hareket kazandırılırken giriş holünün yolcular tarafından daha rahat algılanması da sağlanmıştır (Şekil 11). 

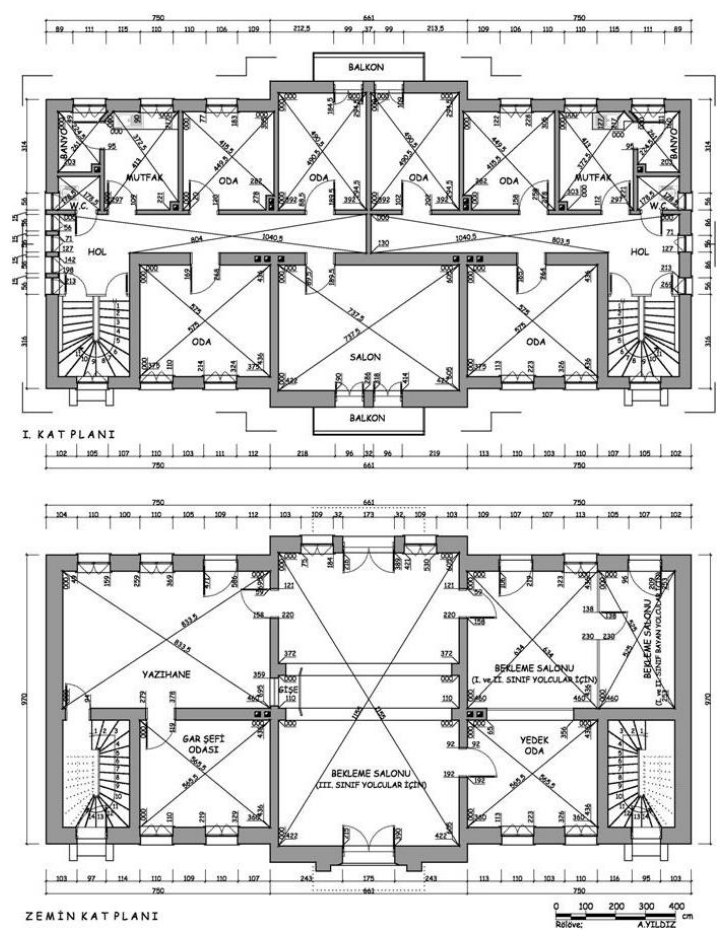

Şekil 11. Yolcu binası kat planları, rölöve [4]

Yapı ana kütlesinin üzeri beşik çatı ile örtülmüş, çatının dar kenarları tepe mahyasına yakın bir hizada kırılarak yarım kırma çatı düzeni oluşturulmuştur. Ana kütlenin üzerini örten bu çatıya dik bir şekilde saplanan giriş holünün beşik çatısı ile yarım kırma-haçvari çatı şekli elde edilmiştir. Bu çatı şekliyle giriş holü daha fazla belirginleștirilmiştir. Giriş holünün üst kısmındaki üçgen alınlıklar, pencere ve kapı etrafindaki silmeler ve bezemeler, giriş holünün birinci katındaki balkon kapılarının üst kısımları ve yan cephelerdeki dar pencerelerin üst kısımları hizasındaki yatay kornişler ve saçak silmeleri ile Neoklasik üslup vurgulanmıştır (Şekil 12). Taşıyıcısı ahşap olan çatı, asma-oturtma sistemlerin birlikte kullanıldığı makaslara taşııılmaktadır. Çatı arasının havalandırılması ve aydınlatılması için her iki yan cephedeki kalkan duvarında birer pencere açılmıştır. Yan cephelerde birinci kat koridorunun aydınlatılabilmesi için dar ve yüksek pencereler düzenlenerek dış cepheye de hareket kazandırılmıştır. Bina tuğla malzemeden kâgir yığma olarak inşa edilmiş, bodrum kat tavan döşemesi volta döşeme olarak, zemin ve birinci kat tavan döşemeleri de ahşap kirişlerle oluşturulmuştur. Yapının bölücü duvarları da ahşap konstrüksiyon ile inşa edilmiş, ahşap eleman kullanılan duvar ve tavan kısımlarında bağdadi sıva uygulanmıştır. Yapının özgün projesinde birinci kat peron cephesinde cumba tasarlanmış olup uygulama esnasinda bu kisım balkon olarak inşa edilmiştir (Şekil 13).

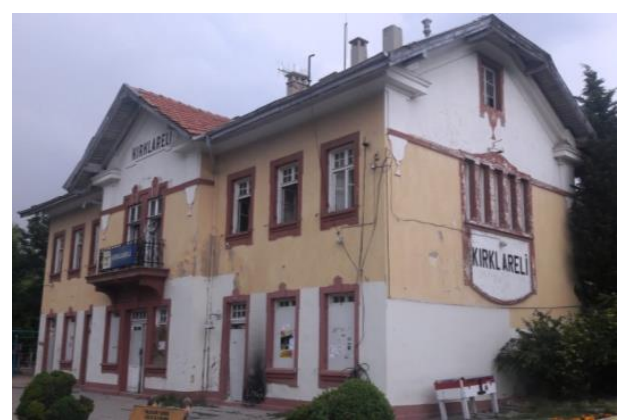

Şekil 12. Yolcu binas1, peron cephesi

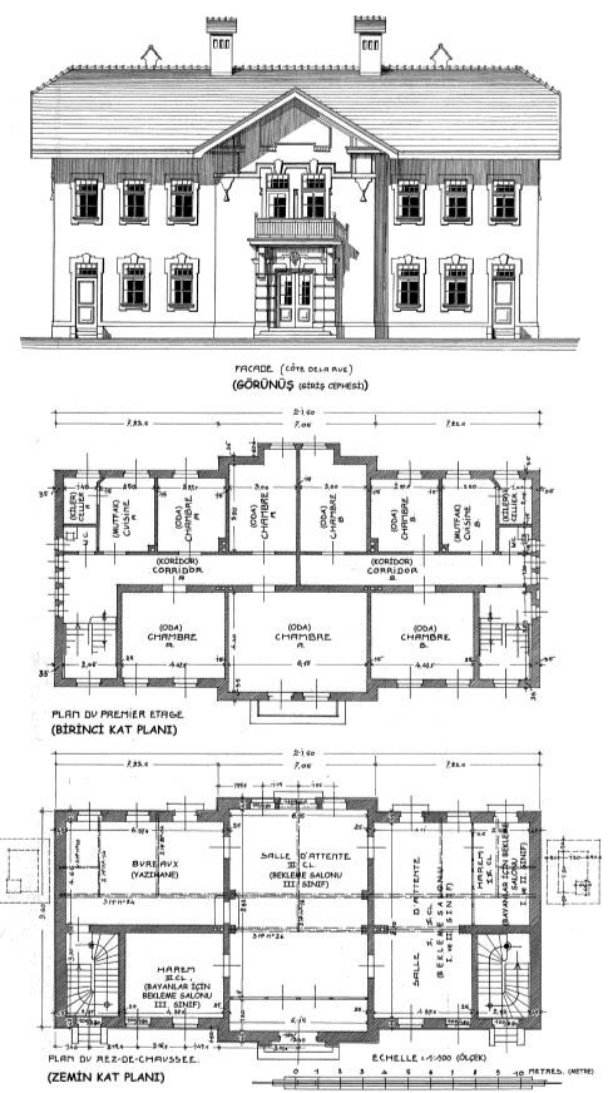

Şekil 13. Yolcu binasının özgün projesi [12] 
Yap1 günümüzde de özgün durumunu büyük ölçüde korumakta olup, birinci katında bulunan kiler kısımları zaman içerisinde banyoya dönüştürülmüştür. Yapının bodrum katına inen merdivenleri yıkılmış ve bodrum kısmen su ile dolmuş, kuranglez boşlukları da zaman içerisinde toprak ile dolarak kapanmıştır. İç duvar ve tavan kaplamaları yer yer dökülmüş, pencerelerin dış kısımlarında yer alan ahşap kepenkler sökülmüştür. Yapının kullanımı terk edilerek, peron cephesindeki zemin kat kap1 ve pencereleri metal levhalarla kapatılmıştır. Yapıya ek bir yük getirilmeden ve özgün plan yapısı ile cephe karakteri korunarak yüklenecek yeni fonksiyonlar müze, konut, konukevi, kreş, kafeterya, restoran olmak üzere sınırlı bir çerçevede değerlendirilebilmektedir. Bunun yanında yapının resmi kurumlar için ek hizmet binası olarak da işlevlendirilmesi mümkündür. Çalışmada alandaki diğer yapılar için önerilen işlevler ile ilişkili olarak binanın cephe düzeni bozulmadan, plan yapısında da geriye dönülebilir bir biçimde yapılacak eklemelerle butik otel olarak işlevlendirilmesi önerilmektedir. Böylece yapının sürdürülebilir bir fonksiyon ile korunması sağlanabilecektir (Şekil 14).
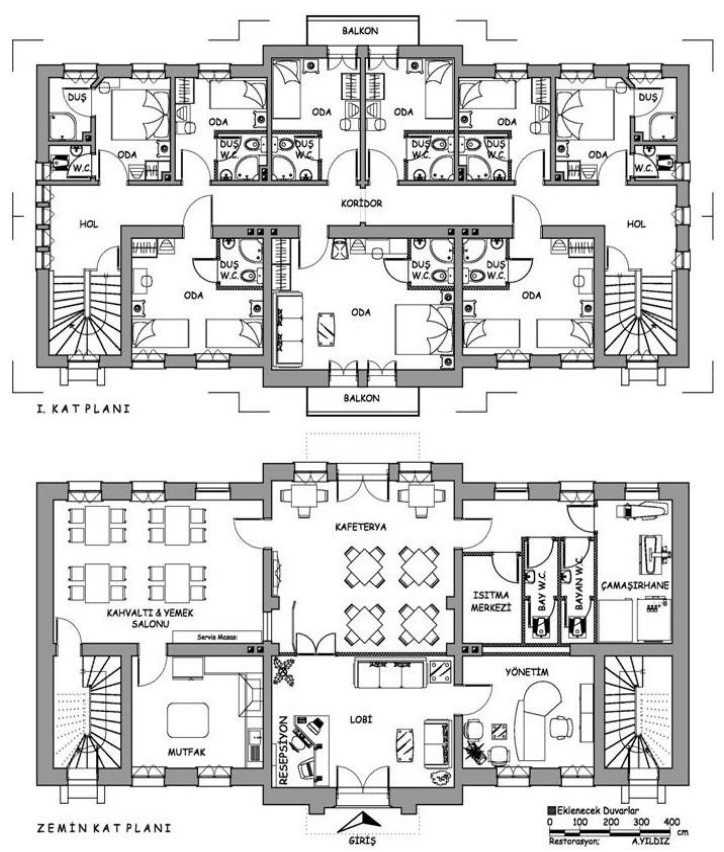

Şekil 14. Yolcu binası kat planları, restorasyon I
Ancak bu şekildeki bir kullanım, her oda için duş ve tuvalet hacimlerine gereksinim duyulması nedeniyle yapıya ek yük getirecektir. Dolayısıyla yapının resmi kurumlarca (belediye, rektörlük, il özel idaresi v.b.) ek hizmet binası olarak kullanılması hâlinde özgün mimarisi büyük oranda korunabilecektir (Şekil 15). Yapıya yüklenecek yeni fonksiyona bağlı olarak oluşturulacak ihtiyaç programı dahilinde kullanım alanı, bodrum ve çatı arası hacimleri ile peron kısmındaki rayların üzerine yerleştirilecek nostaljik vagonlar ile arttırılabilir.

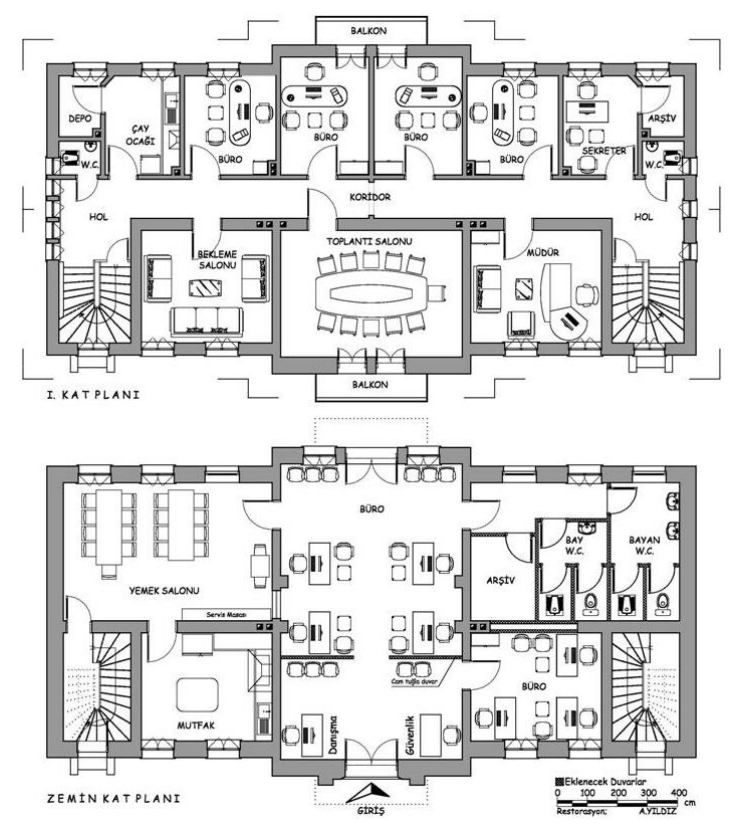

Şekil 15. Yolcu binası kat planları, restorasyon II

\subsection{Makasçı Binası}

Dikdörtgen planlı, uzun kenarı demiryolu hattına paralel olarak inşa edilen yapı, simetrik olarak tasarlanmış birbirine bitişik iki daireden oluşmaktadır. $\mathrm{Bu}$ daireler makasçı personeline lojman olarak tahsis edilmiştir. İki ailenin kullanımı için projelendirilen yapının dairelerini birbirinden ayıran ara duvarında zaman içerisinde açılan bir kapı ile bina tek ailenin kullanabileceği müstakil bir konuta dönüştürülmüştür. Bodrum ve zemin kattan oluşan binanın bodrum kısmına girişin sağlandığ edilememiştir. Bodrum kat tavan döşemesi volta 
döşeme olan yap1, tuğla yığma olarak inşa edilmiştir. Zemin kat tavanı ise, ahşap kirişlemeler üzerine çakılan kaplama tahtası ile oluşturulmuş, çatısı ahşap konstrüksiyon ile beşik çatı olarak tanzim edilmiştir. Çatı arasının havalandırılması için her iki yan cephede de birer küçük pencere açılmıştır. Pencere ve kapı açıklıklarının etrafı, yapı köşeleri, alın ve kalkan duvarlarının kenarları silmeler ile çevrilerek açıklıklar vurgulanmış, cephelere hareket kazandırılmıştır. Pencere-kapı üst kısımlarındaki silmelere kavis verilmiş ve ayrıca orta kısımlarında kilit taşı şeklinde süslemeler yapılmıştır, böylece basık kemer görünümü elde edilmiştir (Şekil 16).

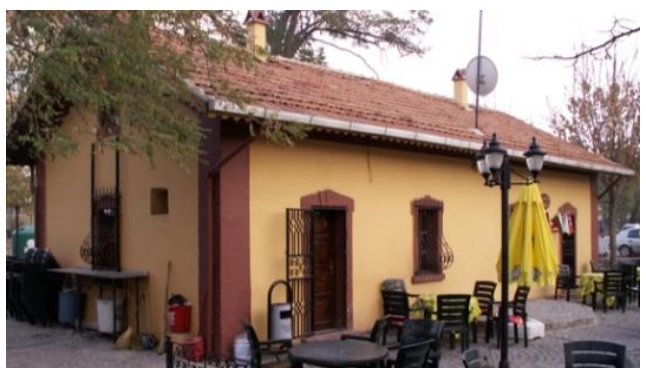

Şekil 16. Makasçı binası, peron cephesi

Uzun süre kullanılmayan yapının çatısı belediye tarafından onarılmış, çürüyen çatı elemanları değiştirilmiştir. $\mathrm{Bu}$ onarımın ardından bina bir derneğe kiraya verilmiş, dernek de daha kapsamlı ve koruma anlayışından uzak bir onarım çalışmasının sonucunda yapıyı kafeterya olarak kullanıma açmıştır. Yapılan onarımlar ile mevcut olmayan kapı ve pencere doğramalarının yerine yenileri yerleştirilmiş, tavan döşeme kaplamaları kaldırılmış, çatının alt kısmı ve bacaların etrafı ahşap lambriler ile kaplanmış, iç duvarlardaki sıvaların kaldırılması ile ortaya çıkarılan tuğla yüzeyler cilalanmış, zemin kat taban döşemesinin üzeri laminat parke ile kaplanmış, yapının orta kısmında yer alan duvarın büyük bir bölümü yıkılarak çatı dikmesinin oturduğu kısımda kolon şeklinde küçük bir duvar bırakılmıştır. Yıkılan bu duvar çatı arasında da devam etmekte olup yükünü sadece ahşap kiriş vasıtasıyla altındaki kısa duvara aktarmaktadır (Şekil 17). Restorasyon önerisi ile yapının özgün plan anlayışının yeniden kazandırılarak kafeterya olarak işlevlendirilmesi öngörülmektedir (Şekil 18).

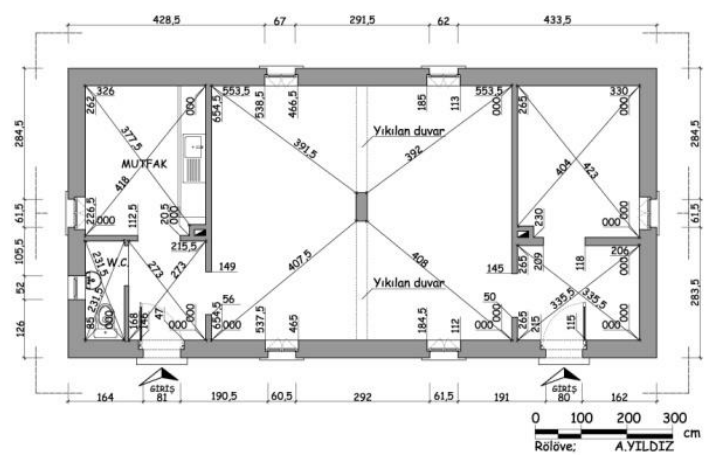

Şekil 17. Makasçı binası, rölöve

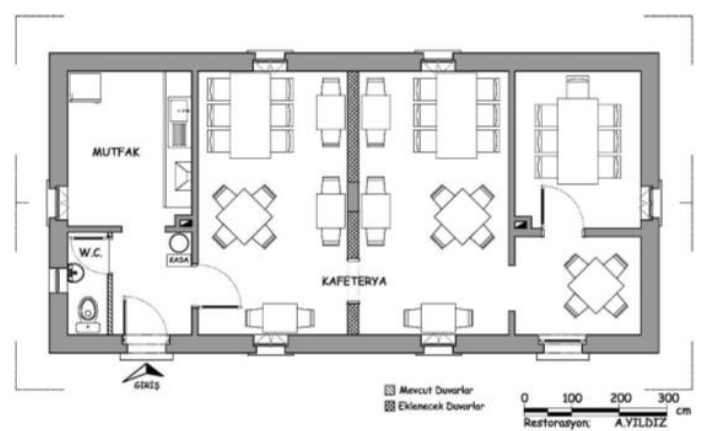

Şekil 18. Makasçı binası, restorasyon

\section{5. Çamaşırhane}

Dikdörtgen planlı, tuğla yığma olarak inşa edilen yapının üst kısmı ahşap makaslı asma çatı ile örtülmüştür. Küçük bir penceresi ve kapısı olan yapının bu açıklıklarının üzeri basık kemer ile geçilmiş ve etrafi alandaki diğer istasyon yapılarında olduğu gibi silmelerle çevrilmiştir. Belediye alanda yaptığı düzenlemeler çerçevesinde yapının çatı örtü malzemesini değiştirmiş, yeni bir pencere doğraması ve kapı ile yapıyı dış etkilerden kısmen de olsa korumuştur. Yapı günümüzde depo olarak kullanılmaktadır. Restorasyon önerisi ile yapının güvenlik ve danışma hizmetleri için kullanılması hedeflenmektedir (Şekil 19).
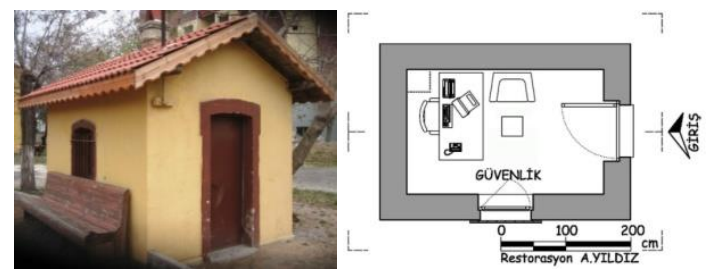

Şekil 19. Çamaşırhane, peron cephesi ve plan 


\subsection{Fen Memuru Binası}

Dikdörtgen planlı, uzun kenarı demiryolu hattına paralel olarak inşa edilen bina bodrum, zemin ve birinci kattan oluşmaktadır. Yapının zemin katında salon, mutfak, banyo ve tuvalet hacimleri; birinci katında ise odalar bulunmaktadır. Katlar arasındaki geçiş yap1 içerisinde düzenlenen ahşap merdivenler ile sağlanmıștır (Şekil 20). Bodrum kata inen merdivenin üzerinin ahşap bir bölme ile bu kısımdaki pencereyi kapatmayacak şekilde, baş yüksekliği dikkate alınarak kapatılmış olduğu duvar yüzeyindeki izlerden anlaşılmaktadır.
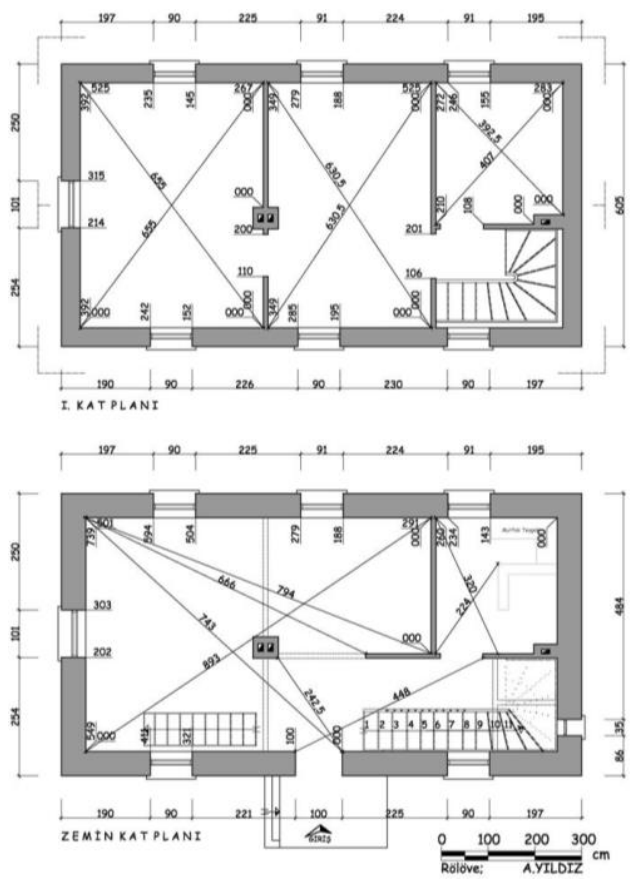

Şekil 20. Fen memuru binası, rölöve

Yapı tuğla malzemeden kâgir yığma olarak inşa edilmiş, bodrum kat tavan döşemesi volta döşeme olarak, zemin ve birinci kat tavan döşemeleri ise ahşap kirişler ile oluşturulmuştur. Binanın üzeri ahşap oturtma beşik çatı ile örtülmüştür. Çatı arasının havalandırılması için yapının her iki yan yüzeyinde birer camsı yuvarlak pencere açılmıştır. Yapıdaki pencere ve kapı açıklıklarının üzeri basık kemer ile geçilirken, birinci kat pencerelerinin iç kısımlarında basık kemer dış kısımlarında ise düz kemer formu uygulanmıştır.
Tüm açıklıkların etrafı silmeler ile çevrilmiş, zemin kat açıklıklarının kemer tepe noktalarında kilit taşı görünümlü bezemeler işlenmiştir. Zemin kat tavan döşemesi hizasında binayı çevreleyen yatay korniş ile kat seviyesi belirginleştirilirken, Neoklasik üslup da vurgulanmıştır (Şekil 21).

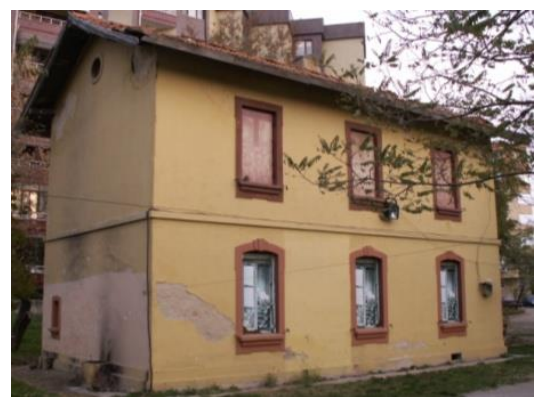

Şekil 21. Fen memuru binası, peron cephesi

Lojman olarak tasarlanan ve uzun süre bu işlevini yerine getiren bina günümüzde metruk hâldedir. Yapıya ek bir yük getirilmeden ve özgün plan şeması korunarak yüklenecek yeni fonksiyonlar konut, pastane, bar, restoran, lokal, kafeterya, kıraathane ve kreş olarak sıralanabilir. Restorasyon önerisi ile pastane olarak yeniden işlevlendirilen yapının, yöresel yiyecek ve içeceklerin satışının yapıldığı bir lokanta olarak hizmet vermesi de öngörülmektedir (Şekil 22).

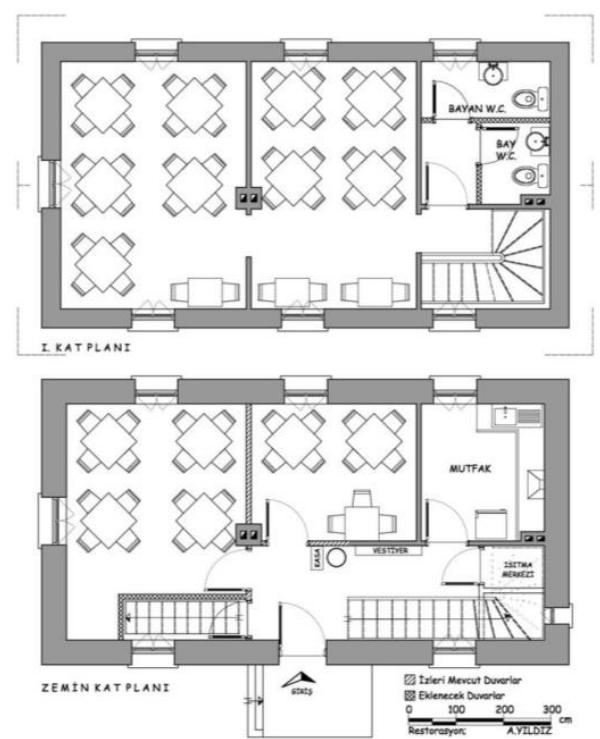

Şekil 22. Fen memuru binası, restorasyon 


\subsection{Su Haznesi}

Dairesel planlı, taş yığma olarak inşa edilen yapının üst kısmına silindir şeklinde metal malzemeden yapılmış bir depo oturtulmuştur. Basık kemerli kapısı üzerindeki kemer taşları ve düzgün taş işçiliği yapıyı alandaki diğer binalardan ayırmaktadır. Yap1 lokomotif deposuna giden demiryolu hattının hemen yanında inşa edilmiş, böylece lokomotif deposuna veya döner köprü ye giden lokomotife ihtiyacı ölçüsünde suyun verilmesi sağlanmıştır. Bunun yanında su deposundan, alanda bulunan diğer istasyon yapılarına kadar su tesisatı döşenerek, yapıların su ihtiyacı da buradan sağlanmıştır. Hattın işlerliğini yitirmesiyle uzun süre kullanılmayan yapı, belediyenin alanda yaptığı çalışmalar kapsamında basit onarımlar geçirmiş, zaman içerisinde yok olan kap1 ve pencerelerinin yerine yenileri yerleştirilmiş, iç kısmında ahşap kirişlemeler üzerine çakılan lambriler ile bir ara tavan oluşturulmuştur. Restorasyon önerisi ile yapının, büfe ve çay ocağı olarak kullanılması amaçlanmıştır. Ayrıca su haznesinin yakınına yerleştirilecek nostaljik bir vagonun içerisinin çayevi veya kıraathane olarak tanzim edilmesi ve bu vagonun önüne buharlı bir lokomotif yerleştirilmesi alanın tarihi dokusuna uygun bir atmosfer oluşturulmasını sağlayacaktır (Şekil 23).
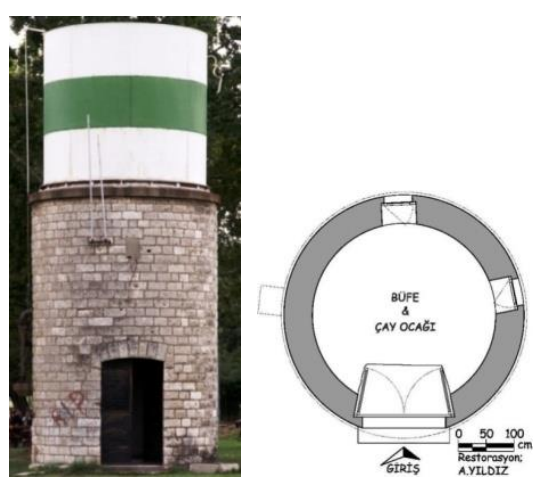

Şekil 23. Su haznesi, ön cephe ve plan

\subsection{Lokomotif Deposu}

Kırklareli istasyon alanındaki son istasyon yapısı olan lokomotif deposu, hattın bittiği yerdeki uç kısımda inşa edilmiştir. Dairesel plan şemasına sahip binanın içerisine aynı anda iki lokomotif alınabilmektedir. Yapının sağ yan cephesine bitişik olarak şef ofisi, işçiler için bir oda, bir torna atölyesi ve tuvalet mekânları tasarlanmıştır (Şekil 24).

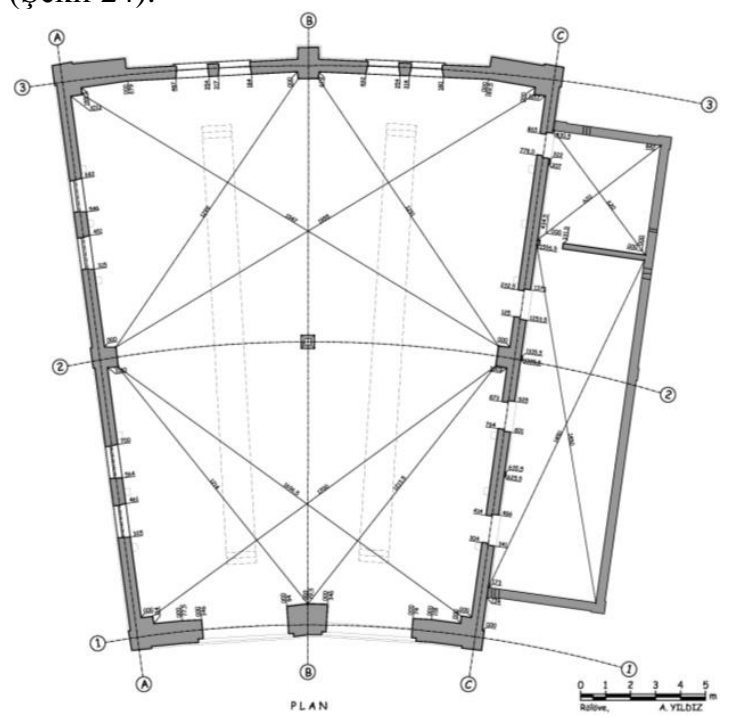

Şekil 24. Lokomotif deposu, rölöve [4]

Yapının içerisine lokomotif alınan ana bölümünün duvarları taş malzemeden, sağ yan cephesine bitişik oluşturulan hacimlerin duvarları ise tuğla malzemeden kâgir yığma olarak inşa edilmiştir. Günümüzde çatısı tamamıyla yok olan bina üst kısmının, arka arkaya iki sıra beşik çatı ile örtülmüş olduğu yapıdaki izlerden anlaşılmaktadır. Lokomotif deposunun kullanımı, hat üzerinde aktif olarak ulaşım hizmetinin sağlandığ 1 son yıllardan itibaren yavaș yavaș terk edilmiștir. Kullanım dıșı kalan yapı, bakımsızlık neticesinde zamanla atmosfer etkileri ve insan eliyle tahrip edilmiş; metal pencere ve kapı doğramaları ile ahşap çatı elemanları sökülerek bina yağmalanmıștır. Bunun neticesinde yapı, atmosfer etkilerine karşı daha fazla savunmasız bırakılmış, nitekim günümüzde yapının sadece beden duvarları ayakta kalabilmiştir (Şekil 25).

Restorasyon önerisi ile uzun süredir kullanılmayan ve yağmalanarak yıkılmaya terk edilmiş hâlde bulunan yapının, mimari karakterinin ve yapım sisteminin yeniden kazandirılarak restoran ve düğün salonu olarak yeniden işlevlendirilmesi 
öngörülmektedir (Şekil 26). Bunun yanında yapıya konferans ve tiyatro salonu olarak ikinci bir restorasyon önerisi de sunulmuştur. Ancak yapının bu şekildeki kullanımı ile bir takım mimari ve statik zorlamalar ortaya çıkmaktadır. Özgün çatı konstrüksiyonu ahşap olan yapının üst örtüsünün, akustik tavan ihtiyacı, havalandırma ve aydınlatma tesisatları nedeniyle çelik konstrüksiyonla oluşturulması gerekmekte, seyirci salonu oturma düzeninin tasarlanması için yapının zeminine kademeli bir çelik konstrüksiyon kurulması ihtiyacı doğmaktadır (Şekil 27).

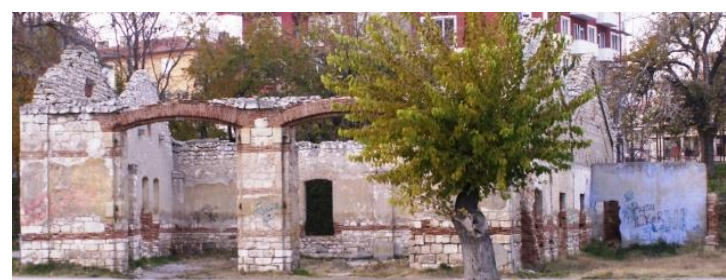

Şekil 25. Lokomotif deposu
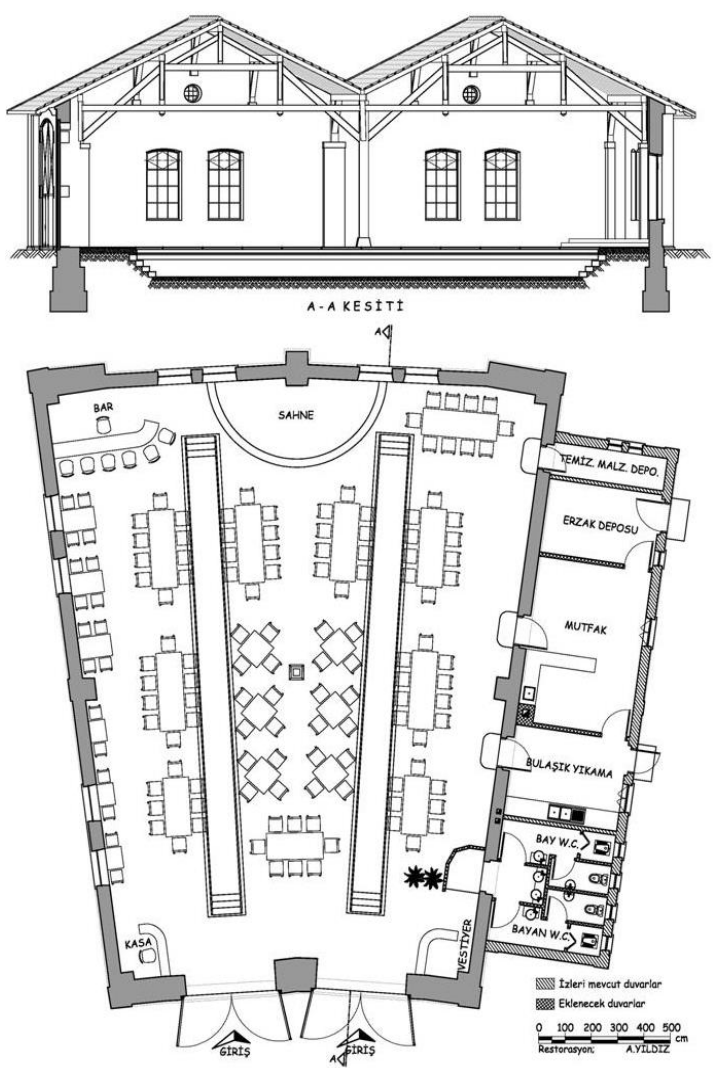

Şekil 26. Lokomotif deposu, restorasyon I

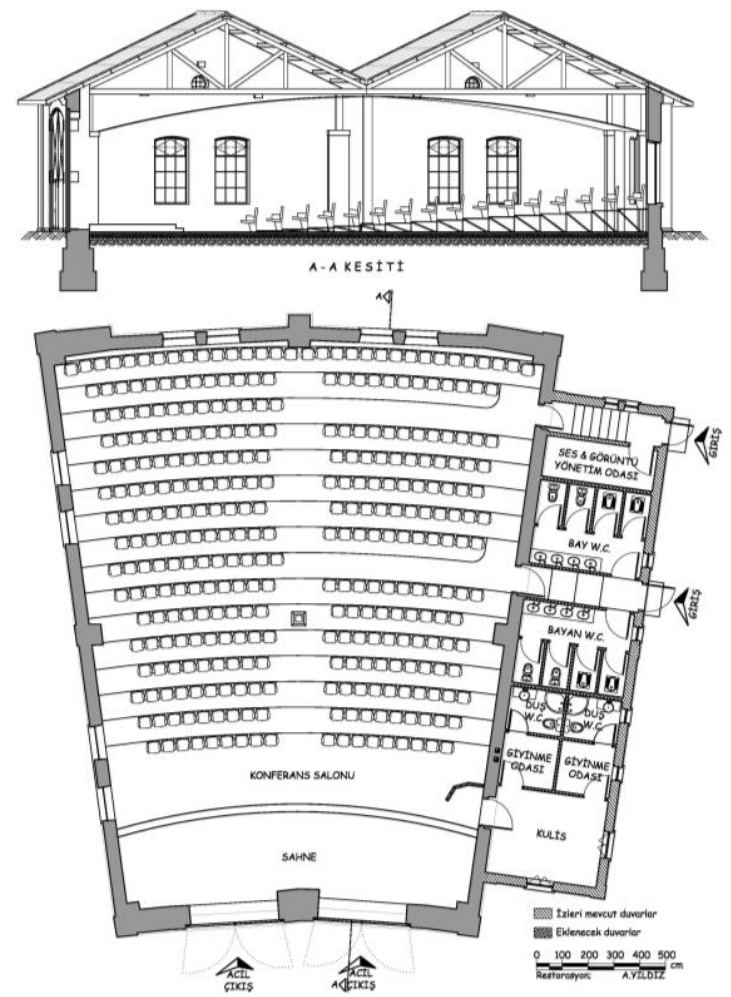

Şekil 27. Lokomotif deposu, restorasyon II

\section{SONUÇ}

İstasyon yapılarının özgün mimari ve yapım tekniklerine sahip olması, köklü bir geçmişe sahip olan demiryolu ulaşımının tarihine ve gelişimine tanıklık etmesi, istasyon alanlarında bulunan yapıların ve tesislerin yok olan bir dönemin demiryolu teknolojisini yansıtması gibi nedenlerle restore edilerek korunması gereklidir.

Kent merkezlerinin gelişmesine bağlı olarak istasyon alanları şehir içerisinde sıkışıp kalmış, günümüz demiryolu teknolojisine hizmet edecek yeni yapıların bu alanlarda inşa edilmesi imkânsız hâle gelmiştir. Bu ve benzeri nedenlerle kullanım dışı kalan istasyon alanları ve barındırdıkları yapılar farklı işlevlerle kent yaşamına kazandırılarak korunmalıdır. Toplumun demiryolu mirasına ilgisini çekmek ve koruma bilincini arttırmak amacıyla işlerliğini yitirmiş hatlar üzerinde turistik amaçlı hizmet verecek buharlı lokomotiflerin ve vagonların işlemesi sağlanarak 
dönemin ulaşım teknolojisi yaşatılabilir. Ayrıca dönem filmlerinin çekimlerinde de kullanılabilecek bu hatlardan işletme giderlerine katkı sağlayacak gelir de elde edebilir.

Çok küçük istasyon alanları haricindeki birçok istasyon alanında birbiriyle ilişkili yapılar inşa edilmiştir. $\mathrm{Bu}$ sebeple istasyon yapılarına getirilecek yeni işlev önerilerinde esneklik pay1 artmakta, yapılarda büyük değişiklikler yapılmaksızın uygun işlev verilebilmektedir. Yeni kullanıma bağlı olarak gereksinim duyulan yeni mekânlar alanda bulunan başka bir yapı içerisinde çözümlenebileceği gibi alanın uygun bir yerine yerleştirilen vagonlar içerisinde de çözümlenebilir. Böylece yapılara yapilabilecek eklerin minimum düzeyde tutulması sağlanırken, yapıların özgün işleviyle ve istasyon alanının tarihi kimliğiyle uyumlu bir atmosfer de oluşturulabilir.

Kırklareli istasyon yapılarının bulunduğu alan içerisinde son zamanlarda rehabilitasyon çalışmaları yapılmış olup, bu çalışmalar sadece çevre düzenlenmesi ölçeğinde kalmıştır. Kullanım dışı kalarak kaderlerine terk edilen Kırklareli Tren İstasyonu yapılarına alanla ilişkili olarak yeni işlev kazandırılması, bu çevrenin tam anlamıla korunarak bir kültür merkezine dönüştürülmesini sağlayacaktır. Kırklareli istasyon alanındaki mevcut istasyon yapıları ile ilgili kapsamlı bir koruma çalışmasına gidilmemiştir. Yok olma tehlikesi ile karşı karşıya olan yapıların kapı ve pencereleri kapatılarak kısmen de olsa bir önlem alındığı söylenebilir fakat bakımsızlık ve yanlış müdahaleler neticesinde yapılar özgünlüğünü yitirmektedir. Nitekim makasçı binası ve emtia ambarı yapılan niteliksiz ve bilimsel gerçeklerden uzak onarımlar sonucunda özgünlüğünü yitirmiştir. Yolcu (gar) binası ve fen memuru binas1 bakımsızlık ve dış etkiler nedeniyle günden güne tahrip olurken, lokomotif deposunun sadece beden duvarları ayakta kalmıştır.

Yapıların restore edilerek yeniden kullanıma açılması koruma yaklaşımı açısından büyük önem arz etmektedir. $\mathrm{Bu}$ kapsamda Kırklareli istasyon alanındaki yapıların yüklenecek yeni fonksiyonlar ile sürekli kullanımı sağlanmalıdır. Böylelikle mimari ve endüstriyel miras niteliğindeki bu yapıların yaşatılması ve korunarak gelecek nesillere aktarılması misyonu da yerine getirilebilecektir. Ayrıca yeni kullanımlarıyla istasyon yapılarının ve bulunduğu alanın şehrin kültürel ve sosyal yaşamına da katkı sağlaması hedeflenmektedir.

\section{KAYNAKLAR}

1. Dursunkaya, A.R. 1948. Kırklareli Vilayetini Tarih, Coğrafya, Kültür ve Eski Eserleri Yönünden Tetkik, I. Cilt, Yeşilyurt Basımevi, Kırklareli.

2. Ali, M. 1930. Balkan Yarımadası Demiryolları (Bulgaristan, Yunanistan, Avrupayi Türkî, Yugoslavya), Demiryollar Mecmuası, say1: 70, 499-507, Haydarpaşa Devlet Demiryolları ve Limanları İstatistik Şubesi, İstanbul.

3. Onur, A. 1953. Türkiye Demiryolları Tarihi (1860-1953), KKK Yayınları, İstanbul.

4. Yıldız, A. 2008. Tarihi Tren İstasyonlarının Çağdaş Kullanımları; Kırklareli Tren İstasyonu'nun Rehabilitasyonu, Yüksek Lisans Tezi, Trakya Üniversitesi, Fen Bilimleri Enstitüsü, Edirne.

5. Araz, M. 1995. Impacts of Political Decisions in the Formation of Railroads and Railroad Architecture in Turkey Between 1856 and 1950, Yüksek Lisans Tezi, Ortadoğu Teknik Üniversitesi, Sosyal Bilimler Enstitüsü, Ankara.

6. Meeks, C.L.V. 1956. The Railroad Station: An Architectural History, Yale University Pres, New Haven, United States of America.

7. Köşkeroğlu, E., 2006. Demiryolu Mirası Korunmas1, Dosya 03, TMMOB Ankara Şubesi Yayınları, Bülten 45,19-23, Ankara.

8. Coulls, A. 1999. Railways as World Heritage Sites, ICOMOS, Paris, France.

9. http://whc.unesco.org/en/list/ (21.07.2017).

10. Burman, P. 1997. Philosophies for Conserving the Railway Heritage, E\&FN Spon, p. 18-34, London.

11. Erkan, Y.K. 2007. Anadolu Demiryolu Çevresinde Gelişen Mimari ve Korunması, Doktora Tezi, İstanbul Teknik Üniversitesi, Fen Bilimleri Enstitüsü, İstanbul.

12. TCDD Genel Müdürlüğü Yol Dairesi Arşivi, 2007. 
